\title{
Determinants of asthma in Ethiopia: age and sex matched case control study with special reference to household fuel exposure and housing characteristics
}

\author{
Yonas Abebe ${ }^{1 *} \mathbb{D}$, Ahmed Ali ${ }^{1}$, Abera Kumie ${ }^{1}$, Tewodros Haile ${ }^{2}$, Mulugeta Tamire ${ }^{1}$ and Adamu Addissie ${ }^{1}$
}

\begin{abstract}
Background: Asthma is a chronic inflammatory disorder characterized by airway obstruction and hyper-responsiveness. Studies suggest that household fuel exposure and housing characteristics are associated with air way related allergy. But there remains to be a considerable uncertainty about whether that reflects an association with asthma. This study endeavored to bridge the gap by identifying factors associated with asthma, with special reference to household fuel exposure and housing characteristics in selected public hospitals in Addis Ababa, Ethiopia.

Methods: We conducted a hospital-based matched case-control study. A total of 483 study participants were selected from two Ethiopian referral hospitals using a sequential sampling technique, with 161 cases and 322 controls. Standard questionnaire from the European Community Respiratory Health Survey II (ECRHS II) and the American Thoracic Society Division of Lung Disease (ATS-DLD-78) were used to collect household related data. Conditional logistic regression model was applied to identify the determinants of asthma. Both crude and adjusted odds ratios with $95 \%$ confidence interval $(\mathrm{Cl})$ were used to identify predictors of asthma.
\end{abstract}

Results: The response rate for both cases and controls was $99.17 \%$. The odds of developing asthma was about four times higher among those who used agricultural residues for cooking (AOR: 3.81, 95\% Cl: 1.05, 13.79)., about five times higher among those who used wood for cooking (AOR: 4.95, 95\% Cl: 2.1, 11.69), nearly five times higher among those who had family history of asthma (AOR: $4.72,95 \% \mathrm{Cl}: 1.54,14.45$ ), just over six times higher among those who smoke tobacco (AOR: $6.16,95 \% \mathrm{Cl}: 1.31,29.09)$ and over ten times higher among those who do not practice door opening, while cooking (AOR: 10.25, 95\% Cl: 3.97, 26.49).

Conclusion: Family history of asthma, tobacco smoking, use of solid fuels including, woods and agricultural residues were associated with development of asthma. To reduce the risk of asthma, people should practice door opening, while cooking, and must avoid using wood and agricultural residues for cooking and should also refrain from tobacco smoking.

Keywords: Household fuel exposure, Biomass fuel, Housing characteristic, Matched case control, Asthma, Ethiopia

*Correspondence: yonasabebe3367@gmail.com

${ }^{1}$ Department of Preventive Medicine, School of Public Health, College of Health Sciences, Addis Ababa University, Addis Ababa, Ethiopia

Full list of author information is available at the end of the article

\section{Introduction}

Asthma is a chronic inflammatory disease of airways of the lungs [1]. According to the Global Asthma Network report, Global Initiative for Asthma (GINA), approximately 339 million people, including six million children original author(s) and the source, provide a link to the Creative Commons licence, and indicate if changes were made. The images or other third party material in this article are included in the article's Creative Commons licence, unless indicated otherwise in a credit line to the material. If material is not included in the article's Creative Commons licence and your intended use is not permitted by statutory regulation or exceeds the permitted use, you will need to obtain permission directly from the copyright holder. To view a copy of this licence, visit http://creativecommons.org/licenses/by/4.0/. The Creative Commons Public Domain Dedication waiver (http://creativeco mmons.org/publicdomain/zero/1.0/) applies to the data made available in this article, unless otherwise stated in a credit line to the data. 
have bronchial asthma [2]. Globally, around three billion people and $90 \%$ of rural households in developing countries rely on kerosene, biomass and coal as primary source of cooking energy, typically burnt indoors in open fires often causing extreme pollution $[3,4]$.

There are a lot of risk factors associated with the occurrence of asthma, such as indoor biomass cooking, outdoor pollution and occupational exposure, particularly in developing countries $[5,6]$. Variations in home characteristics, household crowding, indoor smoke and poverty have been independently associated with asthma [7]. Researches show that biomass fuel is associated with increase in the risk of developing of asthma by increasing the concentration of indoor air pollutants $[8,9]$. Not only biomass fuel, but also indoor cooking with gas stoves are positively associated with both allergy and asthma prevalence [10]. In contrast to the above studies, another research concludes that there is no significant association between indoor air pollutants from biomass fuel use and respiratory diseases, especially asthma [11]. The risk factors for asthma have been identified, but the cause of asthma is not known [12]. Social, psychological and physical factors in the environment may increase the risk for Asthma, including poverty, housing conditions and indoor allergen exposures [13]. There are conflicting evidences regarding the association between selected factors (indoor fuel exposure and housing characteristics) and asthma $[10,11,14]$.

Most of the researches on implicated associations between asthma environmental factors are done in developed countries [10,14]. In Africa, only few studies were conducted $[8,14]$. Further, in Ethiopia, few studies tried to assess the risk factors for asthma [15]. It is inappropriate to assume that previously observed relationships between household fuel exposure, housing characteristics and chronic respiratory diseases apply in all contexts [9].

Despite the considerable population at risk worldwide, the effect of exposure to indoor solid fuel smoke has not been adequately studied [16]. There are studies that describe the relation between chronic respiratory diseases and their risk factors. Nevertheless, only few studies explore potential risk factors for asthma, particularly in Ethiopia [17]. Therefore, this study was intended to fill the information gap, particularly in Ethiopia, by studying the association between household fuel exposures and housing characteristics with asthma in Addis Ababa, Ethiopia.

\section{Methods}

\section{Study design, area and period}

A hospital based, matched case control study design was employed. Two referral hospitals, Tikur Anbessa
Specialized Hospital (TASH) and St. Paul Hospital Millennium Medical College (SPHMMC) constituted study facilities. We used availability of spirometry for the diagnosis of asthma, case load (referrals from all over the country) and existence of specialized units (chest unit and internal medicine OPD) as criteria to select the hospitals. The study was conducted between February 1 and August 30, 2020 in Addis Ababa, Ethiopia.

\section{Study population}

The study population comprised of all patients attending study hospitals (chest clinic and internal medicine OPD) in the designated study period. The eligibility criteria for Cases- were Spirometry confirmed asthmatic patients on follow up in the study hospitals chest clinic or internal medicine OPD and whose age were 18 years or older. Controls- were attendees of study hospitals in non-chest clinics of internal medicine OPD for non-asthma health problems. Matched with sex and age, two controls were selected for cases, in the same 5 year age group. (I.e. control age $=$ case age \pm 2 years). We excluded those cases and controls suffering from COPD, lung cancer, PTB and pneumonia and controls with clinical sign or symptom suggestive of asthma.

\section{Sample size calculation}

Sample size was calculated using Epi info version 7 with the assumption of double population formula. The ratio of control to case is (R) 2:1. The prevalence of exposure (selected determinants, such as household biomass fuel exposure, household fossil fuel exposure and household crowding index) among controls are estimated from previous studies that are $10,19.5$ and $34 \%$ respectively [18-20]. Then, after adjusting for 5\% non-response rate, the maximum sample size was taken corresponding to household fossil fuel exposure which were 487 (162 cases and 325 controls).

\section{Sampling procedure}

From each hospital, participants were selected by consecutive/sequential sampling technique based on the proportion of selected hospitals total patient flow as denominator. Based on the proportional allocation total number of patients were 162, including 104 from TASH and 58 from SPHMMC. For each asthma cases, two age and sex matched controls were selected. Both cases and controls were selected from the same hospitals to control for the influence of context variation.

\section{Study variables \\ Dependent variable}

Asthma status (cases and controls). 


\section{Independent variables}

Socio-demographic characteristics: (Age, Residence, Sex, Marital status, Educational status, Occupational status, Monthly income, Religion).

Housing characteristics: (Number of rooms, Number of persons, Household crowding index, Lighting source, Cooking area, Cooking room floor material, Cooking room wall material, Cooking room roof material, Window in cooking room, Window opening, Door opening, Smoke extraction, Cooking time).

Household fuel exposure characteristics: (Stove type (Three stone fire, Shielded mud stove, Wood burning metal stove, Improved charcoal stove, Kerosene stove, LPG (gas) stove, Solar cooker, Grid powered electric stove), Current household fuel type (Wood, Charcoal, Kerosene, Dung, Agricultural residues, Solar, Grid electricity) and Life time household fuel type (Wood, Charcoal, Kerosene, Dung, Agricultural residues, Solar, Grid electricity)),

Pet ownership: (Pet ownership (cat, dog, bird) and Contact with them).

Life style characteristics: (Tobacco smoking status, Shisha smoking status, Alcohol drinking, Chat chewing status, Drug using status, Family history of asthma, Physical activity).

Nutritional status: (Body mass index, Weight, Height).

Co-morbidities (Cardiac, Hypertension, Diabetes, Nerve, Kidney disease, Liver disease, HIV).

\section{Variables and measurements}

- Asthma - is defined based on respiratory symptom typical of asthma and spirometry result (reversibility of airway obstruction i.e. greater than $12 \%$ and $200 \mathrm{ml}$ increase in FEV1 from baseline) following inhalation of bronchodilator [2] .

- Biomass fuel user- In the questionnaire, an individual was considered as biomass fuel user, if he/ she used fuel, including wood, charcoal, plant residues or agricultural waste and animal dung, mainly from domesticated animals for cooking or heating purposes. Pertaining to user classification, former biomass user means previously used biomass fuel, but stopped or not used biomass fuel with in the last 12 months, current biomass user means that uses biomass fuel with in the last 12 months and if users either current, former or both called life time user [21, 22].

- Fossil fuel user - In the questionnaire, an individual is considered as fossil fuel user if he/she, uses fuel such as oil, coal, natural gas, kerosene and liquid petroleum gas for cooking. Regarding user classifi- cation, former fossil fuel user means previously used fossil fuel, but stopped or not used fossil fuel with in the last 12 months, current fossil fuel user means that used fossil fuel with in the last 12 months and if users either current, former or both called life time user $[21,23]$.

- Household crowding index: - denoted by the number of co-residents per room. i.e. number of co residents (excluding newborn) divided by number of rooms (excluding kitchen and bathroom) based on this it can be categorized in to three, low when it is less than one, medium when it is between one and two, and high when it is greater than three or more [24].

- Window characteristics- Cooking room shall have at least one window, the minimum total window size shall be at least $8 \%$ of the floor area of the room and ask participants for opening during cooking [25].

- Door characteristics; the environment has an opening in the windward façade and a door in the leeward façade and the minimum requirement door characteristics are width of $0.80 \mathrm{~m}$ and height of $2,10 \mathrm{~m}$ and ask participants for opening during cooking [26] .

- Cooking time: cooking time in this study was measured by asking the following question "how many minutes on average do you spend preparing, cooking and cleaning up each time per day?" And the answer were recorded in to three categories, less than $60 \mathrm{~min}$, between 60 and $120 \mathrm{~min}$, and greater than $120 \mathrm{~min}$ [27].

\section{Data collection procedure}

Data were collected through face to face interview by trained data collectors. The data collection tool used in this study was adopted from the previously peer reviewed studies, European Community Respiratory Health Survey II (ECRHS II) questionnaires and American Thoracic Society division of lung disease (ATS-DLD-78) questionnaires by combining them in to one, and appropriate modifications were made to serve our purpose [28, 29]. The first part addressed demographic and socioeconomic characteristics, while the second part included items related to potentials risk factor predictors, including household cooking, housing characteristics, cooking room characteristics, smoking status, alcohol drinking, family history of asthma, pet ownership, physical activity and obesity. A screening questionnaire was used to exclude any one with asthmatic symptoms from control groups. The survey questionnaire was used for both cases and controls. Data regarding patient's medical information were extracted from patient cards. 


\section{Data quality management}

Eight data collectors (Nurses) and two supervisors (Master in Public Health) participated. Training was given for 3 days on the content of questionnaire, data collection methods, interview techniques, ethical concerns and the purpose of the study. The questionnaire prepared in English was translated to Amharic and back to English to maintain consistency of the questions. Pre testing of the questionnaire was made in Yekatit 12 Hospital on $5 \%$ of study population to ensure the quality of data. Completeness and consistency of the questionnaire were assessed daily by supervisors. Data were entered in to a template prepared on Epi-Info software and inconsistencies on the entered data were reconciled by checking the questionnaire. Data cleaning was done by running frequencies and cross-tabulating with the main outcome variables. Before analysis, missing values and outliers were checked. The data were exported to SPSS version 24 for analysis.

\section{Data analysis procedure}

First, descriptive statistics were computed using frequency distribution and proportions for categorical variables and, mean and standard deviations (SD) for continuous variables were described. Chi-square $\left(\mathrm{x}^{2}\right)$ test was used to assess the level of significant differences. A threshold $p$ value of less than $<0.05$ was used to declare significant association between asthma and its predictors in the chi-square $\left(\mathrm{x}^{2}\right)$ test. Since we used matched case control study design conditional logistic regression were performed. Hence, variables which were found to be associated with asthma were included in the conditional binary logistic regression. Furthermore, different variables were included in the conditional multivariable logistic regression to single out the effect of each covariate with asthma and adjusted odds ratios; with 95\% confidence interval was considered to see the association. Confounders were checked to minimize bias. The model goodness of the test was checked by Hosmer - Lemeshow goodness of fit test. The model is fit at $x^{2}=3.711$ and $p$-value of 0.882 . A 95\% confidence interval for crude and adjusted ORs and a threshold $\mathrm{p}$-value of $<0.05$ were used to decide significance of associations.

\section{Ethical consideration}

Before conducting the study ethical clearance was secured from the Research Ethical Committee of the School of Public Health, College of Health Sciences of the Addis Ababa University. Data collectors got written informed consent from the participants after informed them clearly about the aim of the study and the fact that it has no invasive procedure and harm. Respondents were informed that they could refuse or discontinue participation at any time and they were informed of the fact that Information is recorded without their names being mentioned. Only codes were used to keep it anonymous and maintain confidentiality and privacy of respondents.

\section{Results \\ Descriptive analysis \\ Socio-demographic characteristics of study participants}

From those patients who came for different services at TASH and SPHMMC, out of 487 participants approached, four people were excluded ( 1 case and 3 controls) due to failure to get age and sex matched controls. A total of 483 patients were enrolled in the study, which makes the response rate $99.17 \%$. Spirometry was performed for all 162 cases to confirm the diagnosis of asthma. Baseline spirometry with repeat testing after $15 \mathrm{~min}$ to demonstrate reversibility (increase in FEV1 of $12 \%$ and $200 \mathrm{ml}$ ) after the administration of bronchodilator (salbutamol) was performed. Based on this procedure, patients with an obstructive pattern and reversibility on spirometry were included as cases. Of the 162 subjects, FEV1 was $<60 \%$ in $125(77.16 \%)$ and $60-80 \%$ in 37 (22.84\%).

Among the participant of the study, majority of proportion of ages lies between the age group of 41-60, which shows that $79(49.1 \%)$ cases and $160(49.7 \%)$ respectively and the mean ${ }_{ \pm} \mathrm{SD}$ age of participants was $49.8 \pm 14.1$ and $49.4 \pm 13.8$ for cases and controls respectively. From total participants, more cases $7(4.3 \%)$ than controls $(7(2.2 \%)$ were from rural area. Most of participants were female $98(60.9 \%)$ of cases and $196(60.9 \%)$ of controls. Majority 97(60.2\%) cases and 225(69.9\%) controls were married. With respect to educational status, majority of participants 51(31.7\%) of cases and 95 (29.5\%) controls attained primary education and with regard to occupational status, majority of participants were employed either in government, private or self-87(54\%) of cases and 193(59.9\%) of controls. The average monthly income mean $\pm S D$ for cases and controls were 2790.0 \pm 2923.8 and $2609.7 \pm 2459.2$ ETB respectively. Majority 104(64.6\%) of cases and 218(67.7\%) controls were orthodox (Table 1).

\section{Housing characteristics}

Housing characteristics of cases and controls of the total study population were presented below in (Table 2), majority of person have 2 rooms 59(36.6\%) of cases and 104(32.3\%) of controls. On the other hand mean \pm SD number of room was $2.4 \pm 1.4$ and $1.9 \pm 0.9$ for cases and controls, respectively. And also persons living in the house were four or greater than four which were represented by 102(63.4\%) cases and 164(50.9\%) controls and mean \pm SD number of person was $4.4 \pm 2.2$ and $3.7 \pm 1.8$ for cases and controls, respectively. Among those participant household crowding index value lies between 1 
Table 1 Socio-demographic characteristics of participants in selected public hospitals of Addis Ababa, Ethiopia, 2020

\begin{tabular}{|c|c|c|c|c|}
\hline Variables & $\begin{array}{l}\text { Cases } \\
\text { Number (\%) }\end{array}$ & $\begin{array}{l}\text { Control } \\
\text { Number (\%) }\end{array}$ & $\begin{array}{l}\text { Chi-square } \\
\left(x^{2}\right)\end{array}$ & $P$ value \\
\hline \multicolumn{5}{|l|}{ Age: } \\
\hline$\leq 20$ & $0(0)$ & $2(0.6)$ & & \\
\hline $21-40$ & $45(28)$ & 93(28.9) & 1.299 & 0.862 \\
\hline $41-60$ & $79(49.1)$ & $160(49.7)$ & & \\
\hline $61-79$ & $34(21.1)$ & $61(18.9)$ & & \\
\hline$\geq 80$ & $3(1.9)$ & $6(1.9)$ & & \\
\hline \multicolumn{5}{|l|}{ Residence: } \\
\hline Rural & $7(4.3)$ & $7(2.2)$ & 1.802 & 0.179 \\
\hline Urban & 154(95.7) & 315(97.8) & & \\
\hline \multicolumn{5}{|l|}{ Sex: } \\
\hline Male & 63(39.1) & 126(39.1) & 0.000 & 1 \\
\hline Female & $98(60.9)$ & $196(60.9)$ & & \\
\hline \multicolumn{5}{|l|}{ Marital status: } \\
\hline Single & $25(15.5)$ & $45(14)$ & 7.760 & 0.051 \\
\hline Married & $97(60.2)$ & 225(69.9) & & \\
\hline Widowed & $30(18.6)$ & $46(14.3)$ & & \\
\hline $\begin{array}{l}\text { Separated/ } \\
\text { divorced }\end{array}$ & $9(5.6)$ & $6(1.9)$ & & \\
\hline \multicolumn{5}{|l|}{ Educational status: } \\
\hline $\begin{array}{l}\text { Unable to read and } \\
\text { write }\end{array}$ & $40(24.8)$ & $86(26.7)$ & & \\
\hline Primary (1-8) & $51(31.7)$ & $95(29.5)$ & 0.477 & 0.976 \\
\hline Secondary $(9-10)$ & $18(11.2)$ & $37(11.5)$ & & \\
\hline $\begin{array}{l}\text { Preparatory } \\
(11-12)\end{array}$ & $4(2.5)$ & $10(3.1)$ & & \\
\hline $\begin{array}{l}\text { Diploma and } \\
\text { above }\end{array}$ & $48(29.8)$ & $94(29.2)$ & & \\
\hline \multicolumn{5}{|c|}{ Occupational status: } \\
\hline Unemployed & $55(34.2)$ & 106(32.9) & & \\
\hline Employed & $87(54)$ & 193(59.9) & 3.579 & 0.311 \\
\hline Retired & 18(11.2) & $21(6.5)$ & & \\
\hline Student & $1(0.6)$ & $2(0.6)$ & & \\
\hline \multicolumn{5}{|l|}{ Monthly income: } \\
\hline Less than 500 & $41(25.5)$ & $84(26.1)$ & & \\
\hline $500-1500$ & $35(21.7)$ & $54(16.8)$ & 5.236 & 0.155 \\
\hline $1501-2500$ & 17(10.6) & $57(17.7)$ & & \\
\hline Greater than 2500 & $68(42.2)$ & 127(39.4) & & \\
\hline \multicolumn{5}{|l|}{ Religion: } \\
\hline Orthodox & $104(64.6)$ & $218(67.7)$ & & \\
\hline Muslim & 19(11.8) & $42(13)$ & 6.474 & 0.091 \\
\hline Protestant & $35(21.7)$ & $46(14.3)$ & & \\
\hline Catholic & $3(1.9)$ & $16(5)$ & & \\
\hline
\end{tabular}

Employed (govt,private,self), ETB (Ethiopian Birr)

and 2 were $70(43.5 \%)$ of cases and $151(46.9 \%)$ of controls and Household crowding index mean \pm SD was $2.1 \pm 1.1$ of cases and $2.1 \pm 0.8$ of controls.. Majority of participant use electricity for lighting source $157(97.5 \%)$ of cases and 317(98.4\%)of controls. A high proportion of cases and controls had enclosed area (kitchen) for cooking purpose reported among $117(72.7 \%)$ of cases and 241 (74.8\%) of controls. When we try to see smoke extraction, majority of participant used door opening practice as ventilation system $76(47.2 \%)$ of cases and 162(50.3\%) of controls. On the other hand majority of participants $74(46 \%)$ cases and 304(94.4) controls spent $60-120$ min for cooking a day and mean \pm SD of Cooking time in minute were represented by $97.1 \pm 55.8$ of cases and $94.7 \pm 35.7$ of controls respectively.

\section{Cooking room characteristics}

Cooking room characteristics of cases and controls are presented. Majority of participant cooking room floor material were cement represented by $91(56.5 \%)$ of cases and $187(58.1 \%)$ of controls. With respect to cooking house wall material $63(39.1 \%)$ of cases and $94(29.2 \%)$ of controls, were iron sheet respectively. On the other hand most of participants cooking room roof material were iron sheet 154(95.7\%) of cases and 304(94.4\%) of controls. Based on participants report, 77(47.8\%) of cases and 276(85.7\%) of controls has windows in cooking room. Among those who haves it 76(47.2\%) cases and $273(84.6 \%)$ controls practice window opening during cooking time. on the other hand $114(70.8 \%)$ cases and 299(92.9\%) controls practice door opening during cooking time. The detail of cooking room characteristics of the study participants is presented in the following (Table 3).

\section{Association of different characteristics of participant with asthma}

The conditional multiple logistic regression analysis provided that people who didn't practice door opening, while cooking were at high risk to develop asthma compared with people who had door opening practice while cooking. The odds of developing asthma was found to be 10 times higher among people who don't have door opening practice compared to people who have door opening practice while cooking, (AOR:10.25, 95\% CI, $(3.97,26.49))$.

With regard to ever tobacco smoking status, the conditional bi variable analysis identified that, tobacco use as significant risk factor to develop asthma (COR: 8.23 $(3.10,21.84))$. Its association also persisted when adjusted for confounders. As we hold all other factors in the model constant, the odds of developing asthma was found to be 6 times more likely among smoker compared to nonsmokers, (AOR:6.16, 95\% CI, (1.30, 29.10)).

Compared to people who hadn't family history of asthma, people who had family history of asthma were 5 times more likely to develop asthma, after keeping all 
Table 2 Housing characteristics of participants in selected public hospitals of Addis Ababa, Ethiopia, 2020

\begin{tabular}{|c|c|c|c|c|}
\hline Variables & $\begin{array}{l}\text { Cases } \\
\text { Number (\%) }\end{array}$ & $\begin{array}{l}\text { Control } \\
\text { Number (\%) }\end{array}$ & $\begin{array}{l}\text { Chi-square } \\
\left(x^{2}\right)\end{array}$ & $P$ value \\
\hline \multicolumn{5}{|l|}{ Number of room: } \\
\hline 1 & $44(27.3)$ & $86(26.7)$ & & \\
\hline 2 & $59(36.6)$ & $104(32.3)$ & 1.549 & 0.671 \\
\hline 3 & $34(21.1)$ & $72(22.4)$ & & \\
\hline 4 or greater than 4 & $24(14.9)$ & $60(18.6)$ & & \\
\hline \multicolumn{5}{|l|}{ Number of person: } \\
\hline 1 & $13(8.1)$ & $44(13.7)$ & & \\
\hline 2 & $15(9.3)$ & $30(9.3)$ & 7.954 & 0.047 \\
\hline 3 & $31(19.3)$ & $84(26.1)$ & & \\
\hline 4 or greater than 4 & 102(63.4) & 164(50.9) & & \\
\hline \multicolumn{5}{|l|}{ Household crowding index: } \\
\hline Less than 1 & $31(19.3)$ & $54(16.8)$ & 0.676 & 0.713 \\
\hline $1-2$ & $70(43.5)$ & 151(46.9) & & \\
\hline Greater than 2 & $60(37.3)$ & 117(36.3) & & \\
\hline \multicolumn{5}{|l|}{ Lighting source } \\
\hline Lanterns/gas & $4(2.5)$ & $5(1.6)$ & 0.509 & 0.475 \\
\hline Electricity & 157(97.5) & $317(98.4)$ & & \\
\hline \multicolumn{5}{|l|}{ Cooking area } \\
\hline Enclosed area (Kitchen) & $117(72.7)$ & $241(74.8)$ & 0.265 & 0.876 \\
\hline Semi-open area & $6(3.7)$ & $11(3.4)$ & & \\
\hline Part of main living area & $38(23.6)$ & $70(21.7)$ & & \\
\hline \multicolumn{5}{|c|}{ Smoke extraction/ventilation } \\
\hline Permanent holes in roof & $3(1.9)$ & $0(0)$ & & \\
\hline Eaves spaces & $1(0.6)$ & $2(0.6)$ & 9.854 & 0.131 \\
\hline Chimney & $5(3.1)$ & $3(0.9)$ & & \\
\hline Windows openings & $4(2.5)$ & $12(3.7)$ & & \\
\hline Door opening & $76(47.2)$ & $162(50.3)$ & & \\
\hline Door and window opening & $70(43.5)$ & $138(42.9)$ & & \\
\hline Open area & $2(1.2)$ & $5(1.6)$ & & \\
\hline \multicolumn{5}{|l|}{ Cooking time } \\
\hline Less than $60 \mathrm{~min}$ & $71(44.1)$ & $2(0.6)$ & 125.828 & 0.000 \\
\hline $60-120 \mathrm{~min}$ & $74(46)$ & $304(94.4)$ & & \\
\hline Greater than $120 \mathrm{~min}$ & $16(9.9)$ & $16(5)$ & & \\
\hline
\end{tabular}

independent variables constant, (AOR:4.72, 95\% CI, $(1.54,14.45))$.

Participants who were life time wood user were at high risk to develop asthma. The conditional multivariable analysis indicated that people who use wood in their life time for cooking were 4 times at risk of developing asthma compared to people who didn't use, (AOR:4.95, 95\% CI, (2.1, 11.69)).

With respect to agricultural residues using status, people who use agricultural residues for cooking throughout their life time were found to be at risk to develop asthma compared to those who didn't use agricultural residues for cooking in their life time. The odds of developing asthma was found to be 3 times higher among people who use agricultural residues for cooking compared to people who didn't use agricultural residues throughout their life time for cooking, (AOR:3.81, 95\% CI, (1.05, 13.79)). (Table 4).

\section{Discussions}

We found that door opening practice while cooking as a protective factor for asthma. On the other hand, life time uses of wood and agricultural residues for cooking purpose and tobacco smoking were found to be significant risk factors for asthma. Family history of asthma was also noted to be another risk factor for asthma. 
Table 3 Cooking room characteristics of participants in selected public hospitals of Addis Ababa, Ethiopia, 2020

\begin{tabular}{|c|c|c|c|c|}
\hline Variables & $\begin{array}{l}\text { Cases } \\
\text { Number (\%) }\end{array}$ & $\begin{array}{l}\text { Control } \\
\text { Number (\%) }\end{array}$ & $\begin{array}{l}\text { Chi-square } \\
\left(x^{2}\right)\end{array}$ & $P$ value \\
\hline \multicolumn{5}{|c|}{ Cooking house floor material } \\
\hline Clay/mud & $52(32.3)$ & $99(30.7)$ & 0.465 & 0.926 \\
\hline Cement & $91(56.5)$ & $187(58.1)$ & & \\
\hline ceramic & $9(5.6)$ & $21(6.5)$ & & \\
\hline wood & $9(5.6)$ & $15(4.7)$ & & \\
\hline \multicolumn{5}{|c|}{ Cooking house wall material } \\
\hline Iron sheets & 63(39.1) & 94(29.2) & 7.323 & 0.062 \\
\hline Burned bricks & 38(23.6) & $82(25.5)$ & & \\
\hline Wattle and daub & 59(36.6) & $146(45.3)$ & & \\
\hline Plastic & $1(0.6)$ & $0(0)$ & & \\
\hline \multicolumn{5}{|c|}{ Cooking house roof material } \\
\hline Tiles & $7(4.3)$ & $18(5.6)$ & 6.337 & 0.561 \\
\hline Iron sheets & $154(95.7)$ & $304(94.4)$ & & \\
\hline \multicolumn{5}{|c|}{ Window in cooking house } \\
\hline No & $84(52.2)$ & $46(14.3)$ & 78.328 & 0.000 \\
\hline Yes & $77(47.8)$ & $276(85.7)$ & & \\
\hline \multicolumn{5}{|l|}{ Window opening } \\
\hline No & $85(52.8)$ & $49(15.2)$ & 75.606 & 0.000 \\
\hline Yes & $76(47.2)$ & 273(84.6) & & \\
\hline \multicolumn{5}{|l|}{ Door opening } \\
\hline No & $47(29.2)$ & $23(7.1)$ & 42.110 & 0.000 \\
\hline Yes & 114(70.8) & 299(92.9) & & \\
\hline
\end{tabular}

The odds of developing asthma was 10 times higher among individuals who did not practice door opening while cooking compared with individuals who practiced door opening during cooking (AOR: 10.25, 95\% CI:3.97, 26.49). The association may be due to overcrowding and inadequate ventilation for the presence of smoke measured by elevated $\mathrm{CO} 2$ level, high level of benzene and other VOCs [7]. This may be responsible for the development of asthma. The finding on this study supported by different studies such as that of the study which was conducted in Alaska [7], in Japan [30] and Southern New England [31]. In contrast to that, another study conducted in Peru provides unequivocal report which state that there is no association between door opening practice and asthma [32]. This variation may occur due to area of cooking room and other smoke extraction system.

Those subjects who used agricultural residues in their life time for cooking were almost four times more likely to develop asthma compared to people, who don't use agricultural residues in their life time for cooking (AOR: 3.81, 95\% CI: $1.05,13.79)$. Similarly, the use of wood in their life time for cooking purpose was found to be important predictor for acquiring of asthma in this study. The odds of developing asthma was almost five times higher among subjects who use wood for cooking compared to subjects who do not use wood (AOR: 4.95, 95\% CI: 2.1, 11.69). Finding from this study suggest that the risk of wood smoke exposure for asthma may be confined due to their duration of exposure to the smoke and compromised respiratory system from cooking smoke.

The association between biomass fuel smoke exposure and asthma are confirmed by different researches for instance studies conducted in Turkey [33], in Nigeria [34] and in India $[9,35]$. The assumption for this may be smoke emanating from burning biomass fuels contains toxic pollutants called oxidants, which include volatile organic compound (VOCs), particulate matter (PM), carbon monoxide $(\mathrm{CO})$, and oxides of nitrogen, sulfur and Florine [36]. Because of this oxidative stress, which is imbalance between biological pro-oxidants and anti-oxidant defense system, some changes observed like initiate cytokine production and depression of protective membrane and mediates inflammatory response or worsen asthma due to a compromised anti-oxidant defense system [36]. On the other hand, study conducted in Peru [6] and in Nigeria [37] have showed lack of association between biomass fuel smoke exposure and asthma. The discrepancies between studies may be possible due to variations in cooking area, ventilation system, as well as in type, duration and intensity of biomass fuel smoke exposure.

Tobacco smoking has also been identified as important risk factor for developing asthma by six times (AOR: 6.16, 95\% CI: 1.3, 29.1). Our study yield similar finding with the study conducted in Thailand which state that there is a significant association between smoking and asthma [38]. The justification for this may be the effect of smoking on airway i.e. tobacco smoke flow inward to inflammatory cell like neutrophils, lymphocytes, eosinophils, mast cell and macrophages [39]. Since various inflammatory mediators are released which include lipids, chemokines, cytokines and growth factor and those proteolytic enzymes cause inflammatory damage and bronchial hyper-responsiveness which is hall mark of asthma [39]. On the other hand studies conducted in Britain [40] and Uganda [41] are in contrast with our finding stating that there is no significant association between tobacco smoking and asthma. This could be due to variation in the study population, study design and magnitude of cigarette smoking.

Patients who had family history of asthma were more than four times more likely to develop asthma compared to those who had no family history of asthma (AOR: 4.72, 95\% CI: $1.54,14.45)$. The possible explanation for this association could be either due to hereditary factors or a shared environment by the member of a family contributes to the pathogenesis of asthma [6]. The finding of 
Table 4 Conditional multivariable logistic regression analysis of factors associated with asthma among participants in selected public hospitals of Addis Ababa, Ethiopia, 2020

\begin{tabular}{|c|c|c|c|c|}
\hline Variables & $\begin{array}{l}\text { Cases } \\
\text { Number (\%) }\end{array}$ & $\begin{array}{l}\text { Control } \\
\text { Number (\%) }\end{array}$ & COR at $95 \%, \mathrm{Cl}$ & AOR $95 \%, \mathrm{Cl}$ \\
\hline \multicolumn{5}{|l|}{ Number of person: } \\
\hline 1 & 13(8.1) & 44(13.7) & 1 & 1 \\
\hline 2 & $15(9.3)$ & $30(9.3)$ & $2.08(0.83,5.23)$ & $4.10(0.71,23.76)$ \\
\hline 3 & $31(19.3)$ & $84(26.1)$ & $1.39(0.63,3.08)$ & $2.54(0.60,10.82)$ \\
\hline 4 or greater than 4 & 102(63.4) & 164(50.9) & $2.52(1.20,5.31)$ & $1.42(0.30,6.81)$ \\
\hline \multicolumn{5}{|c|}{ Window in cooking house } \\
\hline No & $84(52.2)$ & $46(14.3)$ & $6.73(4.10,11.05)$ & $1.92(0.01,47.77)$ \\
\hline Yes & $77(47.8)$ & 276(85.7) & 1 & 1 \\
\hline \multicolumn{5}{|l|}{ Window opening } \\
\hline No & $85(52.8)$ & 49(15.2) & $6.42(3.95,10.43)$ & $2.17(0.01,52.66)$ \\
\hline Yes & $76(47.2)$ & 273(84.6) & 1 & 1 \\
\hline \multicolumn{5}{|l|}{ Door opening } \\
\hline No & $47(29.2)$ & $23(7.1)$ & $5.13(2.93,8.96)$ & $10.25(3.97,26.49)^{*}$ \\
\hline Yes & 114(70.8) & 299(92.9) & 1 & 1 \\
\hline \multicolumn{5}{|l|}{ Cooking time } \\
\hline Less than 60 mint & $71(44.1)$ & $2(0.6)$ & 1 & 1 \\
\hline $60-120$ mint & $74(46.0)$ & $304(94.4)$ & $1.03(0.66,1.61)$ & $0.69(0.30,1.59)$ \\
\hline Greater than 120 mint & 16(9.9) & $16(5)$ & $2.31(1.05,5.10)$ & $1.61(0.31,8.23)$ \\
\hline \multicolumn{5}{|l|}{ Stove type: } \\
\hline \multicolumn{5}{|l|}{ Three-stone fire } \\
\hline No & 142(88.2) & 316(98.1) & 1 & 1 \\
\hline Yes & 19(11.8) & $6(1.9)$ & $5.61(2.36,13.37)$ & $0.20(0.01,2.92)$ \\
\hline \multicolumn{5}{|l|}{ Kerosene stove } \\
\hline No & 108(67.1) & 95(29.5) & 1 & 1 \\
\hline Yes & $53(32.9)$ & $227(70.5)$ & $0.21(0.14,0.33)$ & $0.20(0.03,1.34)$ \\
\hline \multicolumn{5}{|c|}{ Current household fuel: } \\
\hline \multicolumn{5}{|l|}{ Wood } \\
\hline No & 119(73.9) & 312(96.9) & 1 & 1 \\
\hline Yes & $42(26.1)$ & $10(3.1)$ & $8.41(4.21,16.77)$ & $5.48(0.43,69.52)$ \\
\hline \multicolumn{5}{|l|}{ Kerosene (Paraffin) } \\
\hline No & $55(34.2)$ & $102(31.7)$ & 1 & 1 \\
\hline Yes & 106(65.8) & $220(68.3)$ & $0.23(0.15,0.35)$ & $3.39(0.45,25.35)$ \\
\hline \multicolumn{5}{|l|}{ Dung } \\
\hline No & 143(88.8) & $315(97.8)$ & 1 & 1 \\
\hline Yes & 18(11.2) & $7(2.2)$ & $5.77(2.28,14.58)$ & $0.62(0.06,6.46)$ \\
\hline \multicolumn{5}{|l|}{ Agricultural residues } \\
\hline No & 145(90.1) & $317(98.4)$ & 1 & 1 \\
\hline Yes & 16(9.9) & $5(1.6)$ & $7.65(2.55,22.96)$ & $0.59(0.04,8.51)$ \\
\hline \multicolumn{5}{|c|}{ Lifetime household fuel: } \\
\hline \multicolumn{5}{|l|}{ Wood } \\
\hline No & 48(29.8) & 239(74.2) & 1 & 1 \\
\hline Yes & 113(70.2) & $83(25.8)$ & $7.11(4.41,11.48)$ & $4.95(2.1,11.69)^{*}$ \\
\hline \multicolumn{5}{|l|}{ Charcoal } \\
\hline No & $11(6.8)$ & 59(18.3) & 1 & 1 \\
\hline Yes & 150(93.2) & 263(81.7) & $3.45(1.73,6.88)$ & $1.36(0.43,4.33)$ \\
\hline \multicolumn{5}{|l|}{ Kerosene (Paraffin) } \\
\hline No & $86(53.4)$ & $53(16.5)$ & 1 & 1 \\
\hline Yes & $75(46.6)$ & 269(83.5) & $0.17(0.10,0.27)$ & $0.61(0.22,1.69)$ \\
\hline
\end{tabular}


Table 4 (continued)

\begin{tabular}{|c|c|c|c|c|}
\hline Variables & $\begin{array}{l}\text { Cases } \\
\text { Number (\%) }\end{array}$ & $\begin{array}{l}\text { Control } \\
\text { Number (\%) }\end{array}$ & COR at $95 \%, \mathrm{Cl}$ & AOR $95 \%, \mathrm{Cl}$ \\
\hline \multicolumn{5}{|l|}{ Dung } \\
\hline No & $107(66.5)$ & $300(93.2)$ & 1 & 1 \\
\hline Yes & $54(33.5)$ & $22(6.8)$ & $7.89(4.20,14.84)$ & $1.23(0.31,4.94)$ \\
\hline \multicolumn{5}{|c|}{ Agricultural residues } \\
\hline No & 103(64) & 299(92.9) & 1 & 1 \\
\hline Yes & $58(36)$ & $23(7.1)$ & $7.38(4.1,13.29)$ & $3.81(1.05,13.79)^{*}$ \\
\hline \multicolumn{5}{|l|}{ Pet } \\
\hline No & $84(52.2)$ & 249(77.3) & 1 & 1 \\
\hline Yes & $77(47.8)$ & $73(22.7)$ & $3.19(2.09,4.87)$ & $1.97(0.86,4.49)$ \\
\hline \multicolumn{5}{|c|}{ Ever tobacco smoking status } \\
\hline No & 139(86.3) & 315(97.8) & 1 & 1 \\
\hline Yes & $22(13.7)$ & $7(2.2)$ & $8.23(3.11,21.84)$ & $6.16(1.30,29.10)^{*}$ \\
\hline \multicolumn{5}{|c|}{ Family asthma history } \\
\hline No & 133(82.6) & 309(96.0) & 1 & 1 \\
\hline Yes & $28(17.4)$ & $13(4.0)$ & $4.66(2.36,9.18)$ & $4.72(1.54,14.45)^{*}$ \\
\hline
\end{tabular}

* Significant at $P<0.05,1=$ reference, COR crude odds ratio, AOR adjusted odds ratio

our study is supported by other studies which were conducted in Australia [38], Thailand [42], Uganda [43], New Zealand [44] and California [45], which concluded that family history of asthma is one of the major risk factor for the development of asthma. The justification for the similarity might be the study setting in which most of the studies were conducted in a hospital setting. However, another study conducted in Britain is not in agreement with our finding, which states that there is no significant relationship between family history of asthma and asthma (42). This may be due to study design and population characteristics.

This study has some limitations. First, assessment of housing characteristics information was obtained by interview, but it would be better if we obtain it through direct physical observation. Since the study was done in two referral hospitals, it may also be affected by selection bias or it might not be generalized to the population with asthma despite our effort to incorporate all referral hospitals which used spirometry to increase its representation. Finally based on our study design and subjects, it is difficult to identify the exact causes of asthma, and we recommend that a further prospective large scale study should be done to identify causes of asthma.

\section{Conclusions}

Use of Wood and agricultural residues for cooking purpose in life time were found to be significant risk factors for asthma. Tobacco smoking was also considered to be another risk for asthma. On the other hand, opening door while cooking was founds to be preventive for asthma. Family history of asthma was noted to have its own contribution for the development of asthma. To reduce the risk of asthma, people should practice door opening while cooking, and must limit and avoid using wood and agricultural residues for cooking and refrain from tobacco smoking.

\section{Abbreviation}

ATS: American Thoracic Society; BMI: Body Mass Index; COPD: Chronic Obstructive Pulmonary Disease; Cl: Confidence Interval; COR: Crude Odds Ratio; CRD: Chronic Respiratory Diseases; DALYS: Disability-adjusted life years; ECRHS II: European Community Respiratory Health Survey II; GBD: Global Burden of Disease; GINA: Global Initiative for Asthma; IAQ: Indoor Air Quality; LRTI: Lower Respiratory Tract Infectious; MMMF: Man Made Mineral Fibers; MOR: Matched Odd Ratio; NCDs: Non Communicable Diseases; OPD: Outpatient Department; OR: Odds Ratio; PTB: Pulmonary Tuberculosis; SD: Standard Deviations; SPHMMC: St, Paul Hospital millennium medical college; SPSS: Statistical Package for Social Sciences; TASH: Tikur Anbessa Specialized Hospital; VOC: Volatile Organic Compound; WHO: World Health Organization.

\section{Acknowledgements}

We would like to acknowledge the School of Public Health, College of Health Sciences of Addis Ababa University for their material support. We will like to thank data collectors and study participants.

\section{Authors' contributions}

YA had full access to all of the data in the study and take responsibility for the integrity of the data and the accuracy of the data analysis. YA, AA, AK, TH, MT and AA contributed substantially to the study design, data analysis and interpretation, and the writing of the manuscript. All authors read and approved the final manuscript.

\section{Funding}

This study has not received any fund.

\section{Availability of data and materials}

The datasets used and/or analysed during the current study are available from the corresponding author on reasonable request. 


\section{Declarations}

\section{Ethics approval and consent to participate}

The institutional review board of Addis Ababa University approved the study protocol and data collectors got written informed consent from the participants

\section{Consent for publication}

Not applicable.

\section{Competing interests}

The authors declare that they have no competing interests.

\section{Author details}

${ }^{1}$ Department of Preventive Medicine, School of Public Health, College of Health Sciences, Addis Ababa University, Addis Ababa, Ethiopia. ${ }^{2}$ Department of Internal Medicine, School of Medicine, College of Health Sciences, Addis Ababa University, Addis Ababa, Ethiopia.

Received: 2 August 2021 Accepted: 14 November 2021 Published online: 25 November 2021

\section{References}

1. Lango DL, Fauci AS, Kasper DL, Hauser SL, Jameson J, Loscalzo J, editors. HARRISONS principle of internal medicine, $18^{\text {th }}$ edition, New York. NY: McGraw-Hill; 2012.

2. Global Initiative For Asthma. Global strategy for asthma Managment and prevention, 2020. available from: www.ginasthma.org

3. World Health Organization (8 May 2018). Household air pollution and health; Household air pollution and health (who.int).

4. Moren A. Schei, Jens O. Hessen, Kirk R. Smith, Nigel Bruce, John McCracken, Lopez. V. Childhood asthma and indoor woodsmoke from cooking in Guatemala. J Expo Anal Environ Epidemiol. 2004;14:110-7.

5. Colin L Robinson, Lauren M Baumann, Karina Romero, Juan M Combe, Alfonso Gomez, Robert H Gilman, et al. effect of urbanisation on asthma, allergy and airways inflammation in a developing country setting. Thorax. 2011; 66: 1051-1057.

6. Gaviola C, Catherine H Miele, Robert A Wise, Robert H Gilman, Devan Jaganath, J Jaime Miranda, et al. Urbanisation but not biomass fuel smoke exposure is associated with asthma prevalence in four resourcelimited settings. Thorax. 2016;71:154-60.

7. Singleton R. Aaron J Salkoski, Lisa Bulkow, Chris fish, Jennifer Dobson, al. LAe. Housing characteristics and indoor air quality in households of Alaska native children with chronic lung conditions. Indoor Air. 2017;27:478-86.

8. Oluwafemi Oluwole, Ganiyu O. Arinola, Dezheng Huo, O.Olopade. C. Biomass fuel exposure and asthma symptoms among rural school children in Nigeria. journal of asthma. 2017; 54:347-56.

9. Kumar R, Nagar JK, Raj N, Kumar P, Kushwah AS, Meena M, et al. Impact of domestic air pollution from cooking fuel on respiratory allergies in children in India. Asian Pac J Allergy Immunol. 2008;26:213-22.

10. Svendsen ER, Gonzales M, Commodore A. The role of indoor enviroment :residential determinant of allergy, asthma and plumonary function. Science of total enviroment. 2018;616-17:1513-23.

11. M. khaleguzzaman, M. Kamijima, K.sakai, N. hamajima, Nakajima T. Indoor air pollution and its impact on children under five years old in bangladish. indoor air. 2007; 17: 297-304.

12. Frieri $\mathrm{M}, \mathrm{O}^{\prime}$ Connor M. Nassef. M. Asthma, stress, and depression in women. Allergy Asthma Proc. 2015:36:256-61.

13. Elizabeth W. Holt, Katherine P. Theall, Rabito. FA. Individual, Housing, and Neighborhood Correlates of Asthma among Young Urban Children. Journal of Urban Health: Bulletin of the New York Academy of Medicine. 2012; 90: 1.

14. S.M.Collin, R. Granell, C. Westgarth, J. murray, Paul E, C. Sterne, et al. Pet ownership is associated with increased risk of non-atopic asthma and reduced risk of atopy in childhood. Clinical \& Experimental Allergy. 2015; 45: 200-10.

15. Sisay Shine, Sindew Muhamud, Demelash. A. Prevalence and associated factors of bronchial asthma among adult patients in Debre
Berhan Referral Hospital, Ethiopia 2018: a cross-sectional study. BMC research note. 2018; 12: 608 .

16. Akshay Sood. Indoor fuel exposure and the lung in both developing and developed countries:. NIH Public Access. 2012; 33(4) 649-65.

17. van Gemerta F, van der Molena T, Jonesb R, Chavannesc N. The impact of asthma and COPD in sub-Saharan Africa. Primary Care Respiratory journal. 2011;20(3):240-8

18. Mohamed N. Lucy ngang, Joseph odhiambo, Janet nyamways, menzies R. home enviroment and asthma in Kenya. Thorax. 1995:50:74-8.

19. Harriet Mpairwe, Milly Namutebi, Gyaviira Nkurunungi, Pius Tumwesige, Irene Nambuya, Mike Mukasa1, et al. Risk factors for asthma among schoolchildren who participated in a case- control study in urban Uganda. eLife Sciences. 2019; 8: 494.

20. Doyin Fagbule, Ekanem. EE. Some environmental risk factors for childhood asthma: a case-control study. Annals of Tropical Paediatrics and International Child Health. 1994; 14:15-19.

21. Albertyn R, Rode H, Millar AJW. Peck. MD. The domestication of fire: the relationship between biomass fuel, fossil fuel and burns. Burns. 2012;38:790-5.

22. Koning HWDE, Smith KR, Last JM. Biomass fuel combustion and health Bulletin ofthe World Health Organization. 1985;63(1):11-26.

23. R. Saidura, E.A. Abdelaziza, A. Demirbasb, M.S. Hossaina, Mekhilefc. S. A review on biomass as a fuel for boilers. Renew Sust Energ Rev 2011;15: 2262-2289.

24. Melki IS, Beydoun HA, Khogali M, Tamim H. Yunis. KA. Household crowding index: a correlate of socioeconomic status and inter-pregnancy spacing in an urban setting. J Epidemiol Community Health. 2004;58:476-80.

25. Mood EW. APHA -CDC recommended minimum housing standards. California: American Public Health Association; 1986.

26. Sacht $H$, Lukiantchuki MA. Windows size and the performance of natural ventilation. Procedia Engineering. 2017:196:972-9.

27. Monsivais P, Aggarwal A, Drewnowsk A. Time spent on home food preparation and indicators of healthy eating. Am J Prev Med. 2014;47(6):796-802.

28. American Thoracic Society (ATS). Recommended respiratory disease questionnaires for use with adults and children epidemiological research. Am. Rev. Respir. Dis. 1978; 118: 10-23.

29. European Community Respiratory Health Survey II Steering Committee. The European Community respiratory health survey II. Eur Respir J. 2002;20(5):1071-9.

30. Cong S, Araki A, Ukawa S, Bamai YA, Tajima S. Association of Mechanical Ventilation and Flue use in heaters with asthma symptoms in Japanese schoolchildren: A cross-sectional study in Sapporo. Japan J Epidemiol. 2014;24(3):230-8.

31. Karen C. Dannemiller, Janneane F. Gent, Brian P. Leaderer, Peccia. J. Influence of housing characteristics on bacterial and fungal communities in homes of asthmatic children. INDOOR AIR International Journal of Indoor Environment and Health. 2016:26: 179-92.

32. Suzanne L. Pollard, D'Ann L Williams, Patrick N Breysse, Patrick A baron, Laura M Grajeda, Gilman RH. A cross-sectional study of determinants of indoor environmental exposures in households with and without chronic exposure to biomass fuel smoke. Environ Health. 2014;13(1):1-12.

33. Kürsat UZUN, Bülent ÖZBAY, Erkan CEYLAN, Mehmet GENCER, ZEHIR. I. Prevalence of chronic bronchitis-asthma symptoms in biomass fuel exposed females. Environ Health Prev Med. 2003:8:13-7.

34. Oluwafemi Oluwole, Ganiyu O. Arinola, Dezheng Huo, Olopade4. CO. Household biomass fuel use, asthma symptoms severity, and asthma underdiagnosis in rural schoolchildren in Nigeria: a cross-sectional observational study. BMC Pulmonary Medicine. 2017; 17(1): 3.

35. Mishra V. Effect of indoor air pollution from biomass combustion on prevalence of asthma in the elderly. Environ Health Perspect 2003; 111(1): 71-78.

36. Roehr B. Environmentalists seek to set research agenda on indoor air pollution. BMJ. 2011; 342: d 3062

37. Jesse D. Thacher, Anders Emmelin, Aboi J.K. Madaki, Thacher. TD. Biomass fuel use and the risk of asthma in Nigerian children. Respir Med. 2013;107:1845-51.

38. Darika Wortong, Naesinee Chaiear, Boonsawat. W. Risk of asthma in relation to occupation: A hospitalbased case-control study. Asian Pac J Allergy Immunol. 2015; 33: 152-60. 
39. S.K. Jindal DG. The relationship between tobacco smoke \& bronchial asthma. Indian J Med Res. 2004;120:443-53.

40. Richard E. Sanya, Bruce J Kirenga, William Worodria, Okot-Nwang. M. Risk factors for asthma exacerbation in patients presenting to an emergency unit of a national referral hospital in Kampala, Uganda. Afr Health Sci. 2014;14:707-15.

41. P M Sturdy CRV, H R Anderson, J M Bland, B K Butland, B D W Harrison, C Peckitt, J C Taylor. Psychological, social and health behaviour risk factors for deaths certified as asthma: a national case-control study. Thorax. 2002; 57: 1034-9.

42. Simone Accordini LC, Ane Johannessen, Laura Portas, Bryndis Benediktsd ottir, Randi Jacobsen Bertelsenet.al A three-generation study on the association of tobacco smoking with asthma. International Journal of Epidemiology. 2018; 47: 1106-17.

43. Harriet Mpairwe MN, Nkurunungi G, Tumwesige P, Nambuya I, Mukasa $\mathrm{M}$, Onen $\mathrm{C}$, et al. Risk factors for asthma among schoolchildren who participated in a case- control study in urban Uganda. eLife Sciences. 2019;8:49496.

44. Kristin Wickens JC. Trudi Kemp, Simon Lewis, Wendyl D'Souza, Gillian sawyer, Louise stone, Sarah Tohill, Jo Kennedy, Tania slater, Natalie rains. A case-control study of risk factors for asthma in New Zealand children. Aust N Z J Public Health. 2001;25(1):44-9.

45. Lisa A. Croen JKG, Cathleen K. Yoshida, Roxana Odouli, Judy Van de Water, Maternal Autoimmune Diseases, Asthma and Allergies, and Childhood Autism Spectrum Disorders. Arch Pediatr Adolesc Med 2005; 159(2): $151-157$.

\section{Publisher's Note}

Springer Nature remains neutral with regard to jurisdictional claims in published maps and institutional affiliations.
Ready to submit your research? Choose BMC and benefit from:

- fast, convenient online submission

- thorough peer review by experienced researchers in your field

- rapid publication on acceptance

- support for research data, including large and complex data types

- gold Open Access which fosters wider collaboration and increased citations

- maximum visibility for your research: over $100 \mathrm{M}$ website views per year

At BMC, research is always in progress.

Learn more biomedcentral.com/submissions 